Review Paper:

\title{
Post-Operative Infections in Spine Procedures: A Brief Review
}

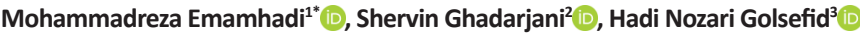

1. Associate Professor of Neurosurgery, Department of Neurosurgery, Poursina Hospital, Guilan University of Medical Sciences, Guilan, Iran 2. Assistant Professor of Neurosurgery, Department of Neurosurgery, Poursina Hospital, Guilan University of Medical Sciences, Guilan, Iran 3. Resident of Neurosurgery, Department of Neurosurgery, Poursina Hospital, Guilan University of Medical Sciences, Guilan, Iran

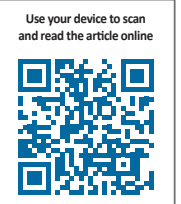

Citation: Emamhadi M, Ghadarjani Sh, Nozari Golsefid H. Post-Operative Infections in Spine Procedures: A Brief Review. Iran J Neurosurg. 2018; 4(1):5-12. http://dx.doi.org/10.32598/irjns.4.1.5

: http://dx.doi.org/10.32598/irjns.4.1.5

Funding: See Page 8

(c) Copyright: The Author(s)

Article info:

Received: 10 September 2017

Accepted: 28 November 2017

Available Online: 01 January 2018

Keywords:

Spine, Surgery, Postoperative, Wound infection

\section{ABSTRACT}

Background and Aim: Surgical site infection is an important complication after spinal surgery. Prevention and treatment of this complication requires more and reliable information. In this article, we investigated the epidemiology, pathogenesis, diagnosis and treatment of post-operative infection in spine procedures by reviewing previous related studies.

Methods and Materials/Patients: In this paper, original articles available in PubMed and Scopus published between 1991 and 2017 were reviewed and studied.

Results: Organisms resistant to antibiotics have increased and made treatment harder, especially in patients with instrumentation of spine. The frequency of surgical site infection depends on surgical technique, anatomical location, and duration of surgery.

Conclusion: Prevention is the best way to reduce the frequency of post-spinal surgical infection. Excessive use of antibiotics increases the risk of infection with bacteria resistant to treatment.

\section{Introduction}

urgical site infection is among the most frequent complications of spine operation. Wound infection is a devastating complication that could happen after simple discectomy or decompressive surgery, fusion, and instrumentation.

Despite improvements in antibiotic prophylaxis, surgery techniques, and post-op care, infections are still threatening patients' lives [1] and impose financial burden to health system [2]. Surgical site infection of spine has long-term, costly outcomes which increases the morbidity and could end up with re-operations or death. The number of individuals resistant to antibiotics is increasing, that makes treatment harder, especially the patients with instrumentation of spine. This review article addresses the etiology, prevention, and treatment of post-operative spinal infection.

* Corresponding Author:

Mohammadreza Emamhadi, MD

Address: Department of Neurosurgery, Poursina Hospital, Guilan University of Medical Sciences, Guilan, Iran

Tel: +98 (13) 33322444

E-mail: mr.emamhadi@gmail.com 
Surgical site infection is the most nosocomial infection that occurs during post-operative period [3]. Different surveys reported prevalence rate of $0.7 \%$ to $16 \%$ for surgical site infection [1-7]. Post-operative infection is $3 \%$ or less after decompressed laminectomy and may increase more than $12 \%$ with fusion and instrumentation [8]. Diskitis is reported to occur in $0.2 \%$ to $2.75 \%$ of surgeries as a rare spine surgery complication [9-12]. Different types of surgery explain incidence of infection varieties, based on the level of invasiveness $[1,13,14]$.

\section{Methods and Materials/Patients}

This article reviews the epidemiology, causes, and treatment of surgical site infection based on previous studies. In this paper, original articles available in PubMed and Scopus published between 1991 and 2017 are used.

\section{Results}

\section{Classification}

Infections after spine surgery are classified into two major groups of superficial and deep. Superficial infections involve skin and subcutaneous tissues with no fascial involvement, but the deep type includes fascia and muscle $[1,13,15-16]$. Diskitis, osteomyelitis, and epidural abscess are among deep infections [13].

Infections are also classified based on the time of happening; the early type occurs within three weeks after the surgery and delayed one develops after four weeks $[13,15-17]$. Another criteria to classify infections consist of organisms cultured from surgical site; type one when only one organism grows in the infection site, type two involves multi-organism growth, and type three refers to multi-organism growth with myonecrosis [2]

\section{Pathogenesis (Microbiology)}

Staphylococcus aureus is the most harvested surgical site infection [1, 18-20]. Other organisms like S. epidermidis, Enterococci spp., Pseudomonas spp., Enterobacter spp., and Proteous spp. grow in descending order $[1,14,19]$. In traumatic patients with spinal fractures, Gram-negative bacteria with urosepsis source are more prevalent and transmit through hematogenous route to surgery site [21]. Immunocompromised patients could be infected by less virulent organisms [22]. There was an increasing incidence of Gram-negative organisms in recent years [19]. Klebsiella spp., E-coli, Pseudomonas spp., and Proteous spp. are the most infectious Gramnegative organisms in acute phase after surgery [8].

There is an increase in Methicillin-resistant Staphylococcus aureus (MRSA) culture of spine surgery site infection recently [21]. In a study, S. aureus SSI rate for spine surgery was $1.0 \%$ (median, $2.0 \%$; range, $0.02 \%-10.0 \%$ ) and pooled average contribution of S. aureus infections to spinal SSIs was $49.3 \%$ and pooled average proportion of S. aureus SSIs attributable to MRSA was 37.9\% [23]. The study determined that preventive strategies aimed specifically at $\mathrm{S}$. aureus SSI could reduce health care costs and improve patient outcomes for spine operations [23]. Risk factors for MRSA colonization consist of antibiotic use within 3 months prior to the operation, hospitalization within 12 months before the surgery, experiencing soft tissue or skin infection during hospitalization, and HIV infection [24, 23].

\section{Risk factors}

Etiologies are generally divided into non-changeable or patient-related factors, and changeable or surgeryrelated factors $[16,26]$. Patient-related risk factors include diabetes mellitus, obesity, alcohol consumption, smoking, old age, corticosteroid use, malnutrition, and histories of more than one week hospitalization $[27,28]$ Other factors like cardiovascular diseases, malignancy, previous lumbar surgery, chronic obstructive pulmonary disease, and immunosuppression are among other factors related to the patient $[20,22,29,30]$.

Poor nutrition intake before the surgery is also a strong risk-factor for post-op infection [31]. Low albumin and WBC levels are believed to be a risk factor for infection, as well $[20,31]$. Obese patients have a thick layer of fat with poor perfusion which is an optimal environment for infection [5, 14, 26, 28, 32, 33]. Diabetic immunodeficiency make the patients susceptible to pathogens, rarely seen and cultured in other patients [34, 35]. Controlling blood glucose level before the surgery is hence very important in diabetic patients, since high glucose level (more than $125 \mathrm{mg} / \mathrm{dL}$ before the operation and above $200 \mathrm{mg} / \mathrm{dL}$ after it) is an independent risk factor for infection [29].

Operation time, blood loss, transfusion, instrumentation and graft use, fusion levels, time spent in recovery room and post-anesthesia care unit, and long hospitalization before the surgery are all important changeable risk factors for infection $[16,20,22,30,31,36]$. 
Duration and complexity of surgery have clear impact on infection, as a simple discectomy has less than $1 \%$ chance for infection but the rate increases to $1.5 \%-2 \%$ in decompressive laminectomy [1, 14, 37]; however, the instrumentation increase the rate to $1.9 \%-4.4 \%$ [5, $6,28,38,39]$. The number of personnel present in the time of surgery (more than 10 people) is another risk factor [20]. It is impossible to remove all risk factors but their reduction will decrease the post-op infection rate $[16,40]$.

\section{Prevention}

Prevention includes assessments and surveys to decrease changeable risk factors in the shortest possible time. Firstly, the less invasive type of chosen surgery is very important, secondly, choosing appropriate instrument should be considered, and lastly, complete treatment of any infection in the patient prior to the surgery [16].

Prophylactic antibiotic use could decrease infection rate to less than $6 \%$ [16], and it is proved to diminish infection rate to less than $1 \%$ after discectomy $[1,15$, 41]. There was also a decrease in infection rate from $7 \%$ to $3.6 \%$ with prophylactic antibiotic use [42]. First generation cephalosporin like cephazoline reach maximum serum level rapidly and have less side-effects compared to other antibiotics. Vancomycin, clindamycin, or ciprofloxacin is an appropriate alternative for patients allergic to these class of antibiotics $[1,16,19,31]$.

Combined prescription of cephazoline with vancomycin is more effective than vancomycin alone in patients with high risk for MRSA colonization [24, 25]. It is believed that cephazoline prophylaxis does not decrease after spinal surgery infection rate, but could diminish the intensity, in case the patient is infected [26]. There is also an increased risk for treatment resistance because of antibiotic prophylaxis overuse [26, 43].

Nutritional state is among adjustable factors. Patients undergoing major spine surgery are preferred to receive a nutritionist consultation at the hospital for oral or even parenteral nutrition supplementation, in order to improve their immunologic condition, and thereby prevent any infection [14]. Theoretically, using drains will diminish infections after the surgery, due to evacuation of the hematoma and seroma in the surgery site [43, 45]. Shaving the surgery site with razors will decrease protecting normal skin flora which also leads to microtrauma and could colonize the bacteria and increase the infection rate [46].

\section{Clinical presentation}

Excessive pain and tenderness and skin swelling around the wound are the prevalent signs of post-op infection. Exudation and dehiscence with redness are common presentations occurring in more than $90 \%$ of cases and less than one-third of the patients experience fever. There is unfortunately a 15-day gap between the surgery and clinical presentations of infection, so the treatment is withhold during this time $[1,47,48]$.

\section{Diagnosis}

Laboratory: Although WBC count is routinely assessed, it is not a reliable criterion for infection, as it may be false negative in infections or even abnormally high in patients without infection. CRP levels are more sensitive than ESR for infection detection and CRP remains high for just 2 weeks, but ESR could be detected high for even 6 weeks $[1,13,15,16,18]$.

Culturing the aspirated collection under the wound is a reliable method for early infection diagnosis [49], but the gold-standard is to culture the tissue harvested in debridement surgery $[1,15,16,18]$. Imaging: X-ray images of spine are not diagnostic for infections, and could just show narrowing of disk space and end-plate erosions $[13,16,18]$. Lucency around the screws might be seen in patients with delayed infections, and CT scans could be used for further evaluations.

\section{Treatment}

Treatment of spine surgery site infection could be very challenging and most patients need long hospitalization, broad-spectrum antibiotic therapy, wound debridement, and instruments removing [3, 22]. Medical treatment could be useful in superficial infections without abscess and fluid collection, ruled-out by imaging [50]. If deep wound infection is detected, the wound should be debrided and irrigated in operation room with general anesthesia, and if there is no necrosis in depth of surgery site and the wound is clean, it could be closed with a vacuum drainage $[1,22,51-53]$.

Epidural and paraspinal abscesses like psoas abscesses, even small ones, may not respond to medical treatment; however, aspiration and drainage under CT guidance are only recommended for large collections [54]. Reoperation and debridement of all necrotic tissue with large amount of saline irrigation is recommended for patients with surgical site infection harboring screw, rod, and fusion [55]. If the patients show the early signs 
of infection, sequestrated bones, loose pedicle screws and unnecessary instruments should be removed, but necessary instruments (removing of which may cause instability) should be kept in place [1, 20, 56-59]. If the infection is an early one, sequestrated bones and loose pedicular screws and unnecessary instruments should be removed, expect for the necessary instruments that should be kept in place, since removing those could lead to instability [1, 20, 56-59].

In case of late infections, especially more than 37 weeks, the instruments should be removed, because arthrodesis has already happened [51-53, 60]. Studies recommend that instrument removal is not necessary in acute infections and they should be remained until arthrodesis occurs [51]. Other studies recommend removing instruments in patients with several debridement procedures who did not respond to antibiotic therapy [61].

Diskitis is a rare after surgery complication with incidence rate of $0.2 \%$ to $2.75 \%$ [9-12]. Percutaneous aspiration with imaging guidance identifies the organism in charge as a potential guide to proper antibiotic choosing [62]. Most patients with diskitis will be treated by proper antibiotic for 6 weeks and spontaneous fusion usually occurs in the disk space $[33,63,64]$.

Spine surgery site infection treatment with antibiotics should be continued for 6 weeks after debridement and if the organism is resistant to treatment including the MRSAs, parenteral antibiotic treatment for 8 weeks is recommended [65]. All deep infection sites in spine operations are in need of long-term treatment with antibiotics [1, 50-52].

\section{Conclusion}

Although surgical site infection after spine procedures is not common, the cost and devastating consequences are among the important challenges of spine surgery. The most important issue is to take preventive measures that could diminish such complications. Appropriate patient selection based on unchangeable risk factors and also the type of surgery and instrument usage should be planned rationally. If the surgery is not emergent, it should be postponed until changeable factors significantly decreased. In other words, the most useful method to decrease this complication is prevention.

Shortening the hospital stay after the surgery will decrease nosocomial and resistant-organism infections. Careful follow-up of patients after discharge is also very important for early diagnosis of infection and starting appropriate treatments.

\section{Ethical Considerations}

\section{Compliance with ethical guidelines}

There were no ethical principles to be considered by the authors.

\section{Funding}

This research did not receive any specific grant from funding agencies in the public, commercial, or not-forprofit sectors.

\section{Conflicts of interest}

There is no conflict of interest to be declared regarding the manuscript. The authors' contribution is as follows: Conception and design: Mohammadreza Emamhadi; Data collection: Hadi Nozari-Golsefid; Drafting the article: All authors; Critically revising the article: All authors; Reviewing submitted version of the manuscript: All authors; and Approving the final version of the manuscript: All authors.

\section{References}

[1] Weinstein MA, McCabe JP, Cammisa FP Jr. Postoperative spinal wound infection: A review of 2,391 consecutive index procedures. Journal of Spinal Disorders \& Techniques. 2000; 13(5):422-6. [PMID]

[2] Thalgott JS, Cotler HB, Sasso RC, LaRocca H, Gardner V. Postoperative infections in spinal implants classification and analysis-a multicenter study. Spine. 1991; 16(8):981-4. [DOI:10.1097/00007632199108000-00020] [PMID]

[3] Horan TC, Culver DH, Gaynes RP, Jarvis WR, Edwards JR, Reid CR. Nosocomial infections in surgical patients in the United States, January 1986-June 1992. National Nosocomial Infections Surveillance (NNIS) System. Infection Control \& Hospital Epidemiology. 1993; 14(2):73-80. [PMID]

[4] Veeravagu A, Patil CG, Lad SP, Boakye M. Risk factors for postoperative spinal wound infections after spinal decompression and fusion surgeries. Spine. 2009; 34(17):1869-72. [DOI:10.1097/ BRS.0b013e3181adc989] [PMID]

[5] Pull ter Gunne AF, Cohen DB. Incidence, prevalence, and analysis of risk factors for surgical site infection following adult spinal surgery. Spine. 2009; 34(13):1422-8. [DOI:10.1097/ BRS.0b013e3181a03013] [PMID]

[6] Fang A, Hu SS, Endres N, Bradford DS. Risk factors for infection after spinal surgery. Spine. 2005; 30(12):1460-5. [DOI:10.1097/01. brs.0000166532.58227.4f] [PMID] 
[7] Smith JS, Shaffrey Cl, Sansur CA, Berven SH, Fu KM, Broadstone PA et al. Rates of infection after spine surgery based on 108,419 procedures: a report from the Scoliosis Research Society Morbidity and Mortality Committee. Spine. 2011; 36(7):556-63. [DOI:10.1097/ BRS.0b013e3181eadd41] [PMID]

[8] Levi AD, Dickman CA, Sonntag VK. Management of postoperative infections after spinal instrumentation. Journal of Neurosurgery. 1997; 86(6):975-80. [DOI:10.3171/jns.1997.86.6.0975] [PMID]

[9] Silber JS, Anderson DG, Vaccaro AR, Anderson PA, McCormick P. Management of postprocedural discitis. The spine Journal : Official Journal of the North American Spine Society. 2002; 2(4):279-87. [DOI:10.1016/S1529-9430(02)00203-6]

[10] Lindholm TS, Pylkkanen P. Discitis following removal of intervertebral disc. Spine. 1982; 7(6):618-22. [DOI:10.1097/00007632198211000-00018]

[11] Tyler KL. Acute pyogenic diskitis (spondylodiskitis) in adults. Reviews in Neurological Diseases. 2008; 5(1):8-13. [PMID]

[12] Tronnier V, Schneider R, Kunz U, Albert F, Oldenkott P. Postoperative spondylodiscitis: results of a prospective study about the aetiology of spondylodiscitis after operation for lumbar disc herniation. Acta Neurochirurgica. 1992; 117(3-4):149-52. [DOI:10.1007/ BF01400612]

[13] Chaudhary SB, Vives MJ, Basra SK, Reiter MF. Postoperative spina wound infections and postprocedural diskitis. The Journal of Spinal Cord Medicine. 2007; 30(5):441-51. [DOI:10.1080/10790268.2007. 11753476] [PMID] [PMCID]

[14] Massie JB, Heller JG, Abitbol JJ, McPherson D, Garfin SR. Postoperative posterior spinal wound infections. Clinical Orthopaedics and Related Research. 1992; 284:99-108. [DOI:10.1097/00003086199211000-00013

[15] Bassewitz HL, Fischgrund J, Herkowitz HN. Academic longevity and attrition of full-time orthopaedic faculty members. The Journal of Bone and Joint Surgery. 2000; (7): 1042-8. [PMID]

[16] Christodoulou AG, Givissis P, Symeonidis PD, Karataglis D, Pournaras J. Reduction of postoperative spinal infections based on an etiologic protocol. Clinical Orthopaedics and Related Research. 2006; 444:107-13. [DOI:10.1097/01.blo.0000201174.10506.cc ] [PMID]

[17] Sasso RC, Garrido BJ. Postoperative spinal wound infections. The Journal of the American Academy of Orthopaedic Surgeons. 2008; 16(6):330-7. [DOI:10.5435/00124635-200806000-00005]

[18] Herkowitz H, Garfin S, Eismont F, Bell G, Balderston R. RothmanSimeone The Spine. Amsterdam: Elsevier Health Sciences; 2011.

[19] Horwitz NH, Curtin JA. Prophylactic antibiotics and wound infections following laminectomy for lumber disc herniation. Journal of Neurosurgery. 1975; 43(6):727-31. [DOI:10.3171/ jns.1975.43.6.0727] [PMID]

[20] Koutsoumbelis S, Hughes AP, Girardi FP, Cammisa FP, Jr., Finerty EA, Nguyen JT, et al. Risk factors for postoperative infection following posterior lumbar instrumented arthrodesis. The Journal of Bone and Joint Surgery American Volume. 2011;93(17):1627-33. [DOI:10.2106/JBJS.J.00039] [PMID]

[21] Rechtine GR, Bono PL, Cahill D, Bolesta MJ, Chrin AM. Postoperative wound infection after instrumentation of thoracic and lumbar fractures. Journal of Orthopaedic Trauma. 2001; 15(8):566-9. [DOI:10.1097/00005131-200111000-00006] [PMID]
[22] Cunningham ME, Girardi F, Papadopoulos EC, Cammisa FP. Spinal infections in patients with compromised immune systems. Clinical Orthopaedics and Related Research. 2006; 444:73-82. [DOI:10.1097/01.blo.0000201176.87635.f3] [PMID]

[23] Patel H, Khoury H, Girgenti D, Welner Sh, Yu H. Burden of surgical site infections associated with select spine operations and involvement of staphylococcus aureus. Surgical Infections. 2017; 18(4):461-73.

[24] Hidron Al, Kourbatova EV, Halvosa JS, Terrell BJ, McDougal LK, Tenover FC, et al. Risk factors for colonization with methicillinresistant Staphylococcus aureus (MRSA) in patients admitted to an urban hospital: Amergence of community-associated MRSA nasal carriage. Clinical infectious diseases : an official publication of the Infectious Diseases Society of America. 2005; 41(2):159-66. [DOI:10.1086/430910] [PMID]

[25] Slover J, Haas JP, Quirno M, Phillips MS, Bosco JA. Cost-effectiveness of a Staphylococcus aureus screening and decolonization program for high-risk orthopedic patients. The Journal of Arthroplasty. 2011; 26(3):360-5. [DOI:10.1016/j.arth.2010.03.009] [PMID]

[26] Rubinstein E, Findler G, Amit P, Shaked I. Perioperative prophylactic cephazolin in spinal surgery. A Double-Blind Placebo-Controlled Trial. The Bone and Joint Journal. 1994 76(1):99-102. [DOI:10.1302/0301-620X.76B1.8300691] [PMID]

[27] Wimmer C, Gluch H, Franzreb M, Ogon M. Predisposing factors for infection in spine surgery: a survey of 850 spinal procedures. Journal of Spinal Disorders. 1998; 11(2):124-8. [DOI:10.1097/00002517199804000-00006] [PMID]

[28] Malone DL, Genuit T, Tracy JK, Gannon C, Napolitano LM. Surgical site infections: reanalysis of risk factors. The Journal of Surgical Research. 2002; 103(1):89-95. [DOI:10.1006/jsre.2001.6343] [PMID]

[29] Olsen MA, Nepple JJ, Riew KD, Lenke LG, Bridwell KH, Mayfield J, et al. Risk factors for surgical site infection following orthopaedic spinal operations. The Journal of Bone and Joint Surgery American Volume. 2008; 90(1):62-9. [DOI:10.2106/JBJS.F.01515] [PMID]

[30] Klein JD, Hey LA, Yu CS, Klein BB, Coufal FJ, Young EP, et al. Perioperative nutrition and postoperative complications in patients undergoing spinal surgery. Spine. 1996; 21(22):2676-82. [DOI:10.1097/00007632-199611150-00018] [PMID]

[31] Dick J, Boachie-Adjei O, Wilson M. One-stage versus two-stage anterior and posterior spinal reconstruction in adults. Comparison of outcomes including nutritional status, complications rates, hospital costs, and other factors. Spine. 1992;17(8 Suppl):S310-6 [DOI:10.1090007632-199208001-00017] [PMID]

[32] Patel N, Bagan B, Vadera S, Maltenfort MG, Deutsch H, Vaccaro $A R$, et al. Obesity and spine surgery: relation to perioperative complications. Journal of Neurosurgery Spine. 2007; 6(4):291-7. [DOI:10.3171/spi.2007.6.4.1] [PMID]

[33] Capen DA, Calderone RR, Green A. Perioperative risk factors for wound infections after lower back fusions. The Orthopedic Clinics of North America. 1996; 27(1):83-6. [PMID]

[34] Carragee EJ. Pyogenic vertebral osteomyelitis. The Journal of Bone and Joint Surgery American Volume. 1997;79(6):874-80. [DOI:10.2106/00004623-199706000-00011] [PMID]

[35] Simionescu R, Grover S, Shekar R, West BC. Necrotizing fasciitis caused by Erysipelothrix rhusiopathiae. Southern Medical Journal. 2003; 96(9):937-9. [DOI:10.1097/01.SMJ.0000051742.81317. E9] [PMID] 
[36] Gelalis ID, Arnaoutoglou CM, Politis AN, Batzaleksis NA, Katonis PG, Xenakis TA. Bacterial wound contamination during simple and complex spinal procedures. A prospective clinical study. The Spine Journal: Official Journal of the North American Spine Society. 2011; 11(11):1042-8. [DOI:10.1016/j.spinee.2011.10.015] [PMID]

[37] Keller RB, Pappas AM. Infection after spinal fusion using internal fixation instrumentation. The Orthopedic Clinics of North America. 1972; 3(1):99-111. [PMID]

[38] Olsen MA, Mayfield J, Lauryssen C, Polish LB, Jones M, Vest J, et al. Risk factors for surgical site infection in spinal surgery. Journal of Neurosurgery: Spine. 2003; 98(2):149-55. [DOI:10.3171/ spi.2003.98.2.0149]

[39] Glassman SD, Dimar JR, Puno RM, Johnson JR. Salvage of instrumental lumbar fusions complicated by surgical wound infection. Spine. 1996; 21(18):2163-9. [DOI:10.1097/00007632-19960915000021] [PMID]

[40] Schuster JM, Rechtine G, Norvell DC, Dettori JR. The influence of perioperative risk factors and therapeutic interventions on infection rates after spine surgery: a systematic review. Spine. 2010; 35(9):S125-37. [DOI:10.1097/BRS.0b013e3181d8342c] [PMID]

[41] Khan IU, Janjua MB, Hasan S, Shah S. Surgical site infection in lumbar surgeries, pre and postoperative antibiotics and length of stay: a case study.Journal of Ayub Medical College Abbottabad. 2009; 21(3):135-8

[42] Meredith DS, Kepler CK, Huang RC, Brause BD, Boachie-Adjei O. Postoperative infections of the lumbar spine: presentation and management. International Orthopaedics. 2012; 36(2):439-44. [DOI:10.1007/s00264-011-1427-z] [PMID] [PMCID]

[43] Watters WC, 3rd, Baisden J, Bono CM, Heggeness MH, Resnick DK, Shaffer WO, et al. Antibiotic prophylaxis in spine surgery: an evidence-based clinical guideline for the use of prophylactic antibiotics in spine surgery. The Spine Journal: Official Journal of the North American Spine Society. 2009; 9(2):142-6. [DOI:10.1016/j. spinee.2008.05.008] [PMID]

[44] Brown MD, Brookfield KF. A randomized study of closed wound suction drainage for extensive lumbar spine surgery. Spine. 2004; 29(10):1066-8. [DOI:10.1097/00007632-200405150-00003]

[45] Beer KJ, Lombardi AV, Jr., Mallory TH, Vaughn BK. The efficacy of suction drains after routine total joint arthroplasty. The Journal of Bone and Joint Surgery American Volume. 1991; 73(4):584-7. [DOI:10.2106/00004623-199173040-00015] [PMID]

[46] Celik SE, Kara A. Does shaving the incision site increase the in fection rate after spinal surgery? Spine. 2007; 32(15):1575-7. [DOI:10.1097/BRS.0b013e318074c39f] [PMID]

[47] Harris AE, Hennicke C, Byers K, Welch WC. Postoperative discitis due to Propionibacterium acnes: a case report and review of the literature. Surgical Neurology. 2005; 63(6):538-41; discussion 41. [DOI:10.1016/j.surneu.2004.06.012] [PMID]

[48] Walid MS, Woodall MN, Nutter JP, Ajjan M, Robinson JS, Jr. Causes and risk factors for postoperative fever in spine surgery patients. Southern Medical Journal. 2009; 102(3):283-6. [DOI:10.1097/ SMJ.0b013e31819676a4] [PMID]

[49] Sponseller PD, LaPorte DM, Hungerford MW, Eck K, Bridwell KH, Lenke LG. Deep wound infections after neuromuscular scoliosis surgery: a multicenter study of risk factors and treatment outcomes. Spine. 2000; 25(19):2461-6. [DOI:10.1097/00007632-20001001000007] [PMID]
[50] Butler JS, Devitt BM, Poynton AR. Hong HS, Chang MC, Liu CL, et al. Is aggressive surgery necessary for acute postoperative deep spinal wound infection? Spine. 2009; 34(7):751-2; author reply [DOI: 10.1097/BRS.0b013e31819d080d] [PMID]

[51] Picada R, Winter RB, Lonstein JE, Denis F, Pinto MR, Smith MD, et al. Postoperative deep wound infection in adults after posterior lumbosacral spine fusion with instrumentation: incidence and management. Journal of Spinal Disorders. 2000; 13(1):42-5. [DOI:10.1097/00002517-200002000-00009] [PMID]

[52] Labler L, Keel M, Trentz O, Heinzelmann M. Wound conditioning by vacuum assisted closure (V.A.C.) in postoperative infections after dorsal spine surgery. European Spine Journal. 2006; 15(9):1388-96. [DOI:10.1007/s00586-006-0164-2] [PMID] [PMCID]

[53] Mehbod AA, Ogilvie JW, Pinto MR, Schwender JD, Transfeldt EE, Wood KB, et al. Postoperative deep wound infections in adults after spinal fusion: management with vacuum-assisted wound closure. Journal of Spinal Disorders \& Techniques. 2005; 18(1):14-7. [DOI:10.1097/01.bsd.0000133493.32503.d3]

[54] Pull ter Gunne AF, Mohamed AS, Skolasky RL, van Laarhoven $\mathrm{CJ}$, Cohen DB. The presentation, incidence, etiology, and treatment of surgical site infections after spinal surgery. Spine. 2010; 35(13):1323-8. [DOI:10.1097/BRS.0b013e3181bcde61] [PMID]

[55] Watanabe M, Sakai D, Matsuyama D, Yamamoto Y, Sato M, Mochida J. Risk factors for surgical site infection following spine surgery: efficacy of intraoperative saline irrigation. Journal of Neurosurgery Spine. 2010; 12(5):540-6. [DOI:10.3171/2009.11. SPINE09308] [PMID]

[56] Sierra-Hoffman M, Jinadatha C, Carpenter JL, Rahm M. Postoperative instrumented spine infections: a retrospective review. Southern Medical Journal. 2010; 103(1):25-30. [DOI:10.1097/ SMJ.0b013e3181c4e00b] [PMID]

[57] Pappou IP, Papadopoulos EC, Sama AA, Girardi FP, Cammisa FP. Postoperative infections in interbody fusion for degenerative spinal disease. Clinical Orthopaedics and Related Research. 2006; 444:120-8. [DOI:10.1097/01.blo.0000203446.06028.b5] [PMID]

[58] Gerometta A, Rodriguez Olaverri JC, Bitan F. Infections in spina instrumentation. International Orthopaedics. 2012; 36(2):457-64. [DOI:10.1007/s00264-011-1426-0] [PMID] [PMCID]

[59] Ahmed R, Greenlee JD, Traynelis VC. Preservation of spinal in strumentation after development of postoperative bacterial infections in patients undergoing spinal arthrodesis. Journal of Spinal Disorders \& Techniques. 2012; 25(6):299-302. [DOI:10.1097/ BSD.0b013e31821fbf72] [PMID]

[60] Viola RW, King HA, Adler SM, Wilson CB. Delayed infection after elective spinal instrumentation and fusion. A retrospective analysis of eight cases. Spine. 1997; 22(20):2444-50. [DOI:10.1097/00007632-199710150-00023] [PMID]

[61] Abbey DM, Turner DM, Warson JS, Wirt TC, Scalley RD. Treatment of postoperative wound infections following spinal fusion with instrumentation. Journal of Spinal Disorders. 1995; 8(4):278-83. [DOI:10.1097/00002517-199508040-00003] [PMID]

[62] Chew FS, Kline MJ. Diagnostic yield of CT-guided percutaneous aspiration procedures in suspected spontaneous infectious diskitis. Radiology. 2001; 218(1):211-4. [DOI:10.1148/ radiology.218.1.r01ja06211] [PMID]

[63] Ozuna RM, Delamarter RB. Pyogenic vertebral osteomyelitis and postsurgical disc space infections. The Orthopedic Clinics of North America. 1996; 27(1):87-94. [PMID] 
[64] Visuri T, Pihlajamaki H, Eskelin M. Long-term vertebral changes attributable to postoperative lumbar discitis: a retrospective study of six cases. Clinical Orthopaedics and Related Research. 2005; (433):97-105. [DOI:10.1097/01.blo.0000151425.00945.2a] [PMID]

[65] Liu C, Bayer A, Cosgrove SE, Daum RS, Fridkin SK, Gorwitz RJ, et al. Clinical practice guidelines by the infectious diseases society of america for the treatment of methicillin-resistant Staphylococcus aureus infections in adults and children. Clinical Infectious Diseases. 2011; 52(3):285-92. [DOI:10.1093/cid/ciq146] [PMID] 
